Nat. Hazards Earth Syst. Sci., 21, 1583-1597, 2021

https://doi.org/10.5194/nhess-21-1583-2021

(C) Author(s) 2021. This work is distributed under

the Creative Commons Attribution 4.0 License.

\title{
Atmospheric conditions leading to an exceptional fatal flash flood in the Negev Desert, Israel
}

\author{
Uri Dayan $^{1}$, Itamar M. Lensky ${ }^{2}$, Baruch $\mathrm{Ziv}^{3}$, and Pavel Khain ${ }^{4}$ \\ ${ }^{1}$ Department of Geography, The Hebrew University of Jerusalem, Jerusalem, 9070227, Israel \\ ${ }^{2}$ Department of Geography and Environment, Bar-Ilan University, Ramat-Gan, 5290002, Israel \\ ${ }^{3}$ Department of Natural Sciences, The Open University of Israel, Raanana, 4353701, Israel \\ ${ }^{4}$ Israel Meteorological Service, Beit Dagan, 5025001, Israel
}

Correspondence: Itamar Lensky (itamar.lensky@biu.ac.il) and Uri Dayan (msudayan@mscc.huji.ac.il)

Received: 31 March 2020 - Discussion started: 29 April 2020

Revised: 21 March 2021 - Accepted: 14 April 2021 - Published: 25 May 2021

\begin{abstract}
The study deals with an intense rainstorm that hit the Middle East between 24 and 27 April 2018 and took the lives of 13 people, 10 of them on 26 April during the deadliest flash flood in Tzafit Basin $\left(31.0^{\circ} \mathrm{N}, 35.3^{\circ} \mathrm{E}\right)$, the Negev Desert. The rainfall observed in the southern Negev was comparable to the long-term annual rainfall there, with intensities exceeding a 75-year return period. The timing of the storm, at the end of the rainy season when rain is relatively rare and spotty, raises the question of what the atmospheric conditions were that made this rainstorm one of the most severe late-spring storms.

The synoptic background was an upper-level cut-off low that formed south of a blocking high which developed over eastern Europe. The cut-off low entered the Levant near $30^{\circ} \mathrm{N}$ latitude, slowed its movement from $\sim 10$ to $<5 \mathrm{~m} \mathrm{~s}^{-1}$ and so extended the duration of the storm over the region. The dynamic potential of the cut-off low, as estimated by its curvature vorticity, was the largest among the 12 latespring rainstorms that occurred during the last 33 years. The lower levels were dominated by a cyclone centred over northwestern Saudi Arabia, producing north-westerly winds that advected moist air from the Mediterranean inland. During the approach of the storm, the atmosphere over Israel became unstable, with instability indices reaching values favourable for thunderstorms (e.g. CAPE $>1500 \mathrm{~J} \mathrm{~kg}^{-1}, \mathrm{LI}=4 \mathrm{~K}$ ) and the precipitable water reaching $30 \mathrm{~mm}$. The latter is explained by lower-level moisture advection from the Mediterranean and an additional contribution of mid-level moist air transport entering the region from the east. Three major rain centres were active over Israel during 26 April, only one of them was oro-
\end{abstract}

graphic and the other two were triggered by instability and mesoscale cyclonic centres. The build-up of the instability is explained by a negative upper-level temperature anomaly over the region caused by a northerly flow east of a blocking high that dominated eastern Europe and ground warming during several hours under clear skies.

The intensity of this storm is attributed to an amplification of a mid-latitude disturbance which produced a cut-off low with its implied high relative vorticity, low upper-level temperatures and slow progression. All these, combined with the contribution of moisture supply, led to intense moist convection that prevailed over the region for 3 successive days.

\section{Introduction}

On 26 April 2018 an extremely intense rainstorm hit Israel. A total of 13 people were killed in this storm, 10 of them by a raging flash flood in the Tzafit Basin $\left(31.0^{\circ} \mathrm{N}, 35.3^{\circ} \mathrm{E}\right)$, north-east of the Negev Desert (denoted in Fig. 1). The rainfall depth during this storm exceeded $20 \mathrm{~mm}$ over most parts of the country except the north-western Negev and the southern tip of the Negev, over most of which the monthly longterm mean does not exceed $10 \mathrm{~mm}$ (Porat et al., 2018).

Flash flood forecast and warning is a challenging task, in particular over remote arid areas where meteorological radar coverage is sparse. Though flash flood warning has much improved in the last few decades, it is still the most weatherrelated fatal hazard globally (Montz and Gruntfest, 2002), with 1075 fatalities between 1996 and 2014 in the United 


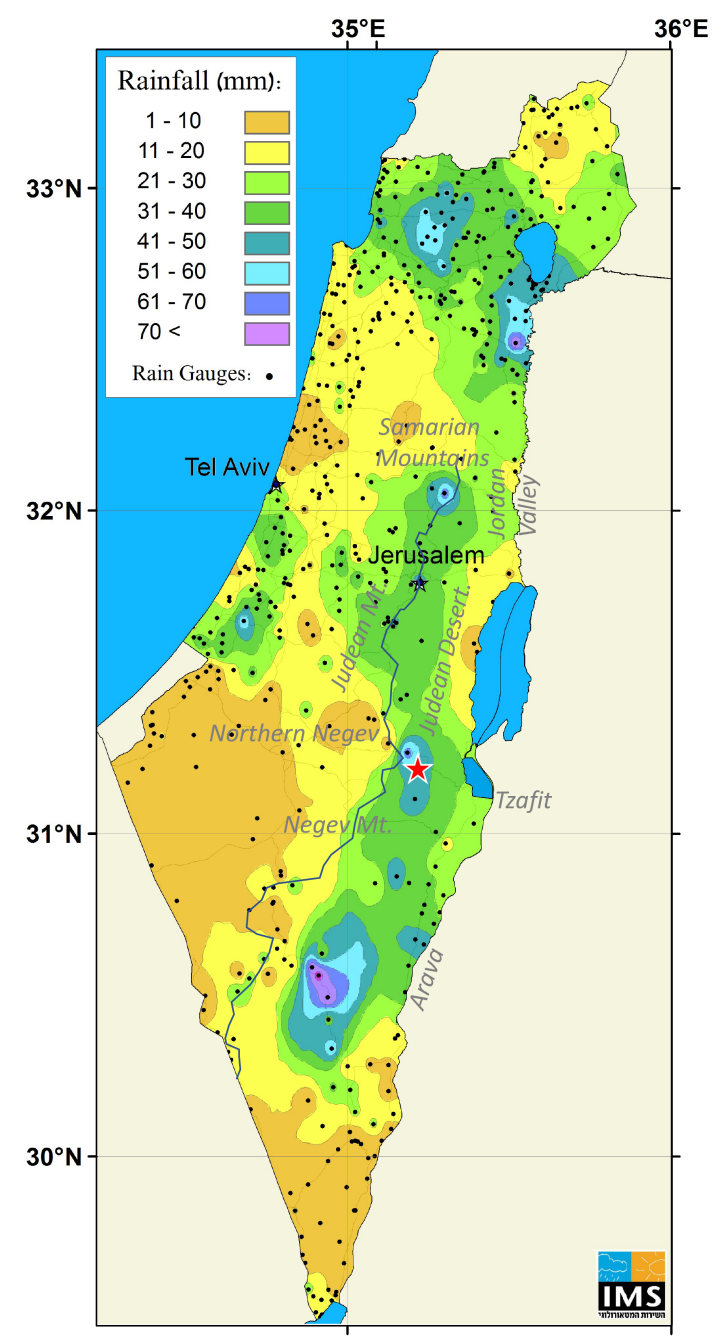

Figure 1. Rainfall distribution over Israel for the period of 25 April 06:00 UTC to 27 April 06:00 UTC 2018 from the IMS radar and rain-gauge measurements based on the INCA system integration method (Haiden et al., 2011). The black line indicates the water divide of the Samarian, Judean and Negev mountains.

States alone (Terti et al., 2017). A significant part of the flash flood leading to fatalities is caused by an incorrect assessment or misjudgement of the risks of these rapidly evolving phenomena (Sharif et al., 2015; Becker et al., 2015; Diakakis et al., 2018).

The study focuses on the Negev Desert and the Judean Desert (Fig. 1), hereafter referred to as the "study region". The climatic regimes of the study region span from semiarid in the north to arid in the centre and the south. The majority of the annual precipitation in Israel is associated with Mediterranean cyclones reaching its eastern part (i.e. Cyprus lows; HMSO 1962; Saaroni et al., 2010; Zappa et al., 2015). Two-thirds of the rainfall occur during December through February (Alpert et al., 2004; Ziv et al., 2006). During the late spring (April and May), the rainfall over the northern and central parts of the Negev Desert constitutes 4\%-9\% of the annual average $(5-10 \mathrm{~mm})$. In spite of these negligible rain amounts, the number of flash flood events cannot be ignored.

The flood regime in the study region was analysed by Kahana (1999), based on 37 hydrometric stations operated by the Israeli Hydrological Service. He identified 59 "major floods" in which the recorded peak discharge reached the magnitude of a 5-year recurrence interval (for the period 1947-1994) at least in one watershed. A total of $14 \%$ of these major floods occurred during the late spring.

The main source of major floods in the late spring over the study region is the active "Red Sea trough" (ARST; Kahana et al., 2002). The RST is a low-pressure system extending from the south toward the eastern Mediterranean (EM) and the Levant (Ashbel, 1938; Kahana et al., 2002; Tsvieli and Zangvil, 2007). The ARST is most frequent during fall and spring (Sharon, 1978; Sharon and Kutiel, 1986; Dayan et al., 2001). The ARST is accompanied by a pronounced upperlevel trough that develops over Egypt and, at times, initiates convective storms over the Levant. The secondary source of major floods is the Syrian Low - a derivative of the Cyprus Low. Syrian lows are Mediterranean mid-latitude cyclones that approach Syria and deepen in contrast to the normal conditions, in which Mediterranean cyclones tend to decay upon reaching Syria (Kahana et al., 2002). The implied winds over Israel during Syrian lows are north-westerly enriched with moisture originating from the Mediterranean that cross the Judean and the Negev mountains perpendicular to the terrain upslope, supporting orographic rains.

The storm analysed here was associated with a Syrian Low accompanied by an upper-level closed cyclone, resembling the features of a "cut-off low" (as is shown in Sect. 3 below). A cut-off low is defined as a closed cyclone in the upper levels, overlapping with a potential vorticity (PV) maximum (e.g. Hoskins et al., 1985). Cut-off lows are considered to be favourable for severe weather over the Mediterranean Basin (Porcu et al., 2007). For instance, in southern Portugal cutoff lows were found to be a major source for heavy rainfall (Fragoso and Tildes Gomes, 2008). Porcu et al. (2007) identified 273 cut-off lows over the entire Mediterranean Basin during the period $1992-2001$. As for the Levant $\left(30-35^{\circ} \mathrm{N}\right.$, $30-35^{\circ} \mathrm{E}$ ), they found six cases (average of $0.6 \mathrm{yr}^{-1}$ ) during the months of April-September. Since the Levant is free of a significant upper-level cyclonic system (and also of rain) during the summer months of June-September (Kushnir et al., 2017), this result reflects, actually, the events of April and May.

This storm was severe in several aspects. One is the number of fatalities, 13, which is record breaking for Israel.

Second, the north-eastern part of the Negev Desert experienced rain intensities reaching a 75-100-year return period, resulting in discharge magnitudes of a 10-50-year return period (Rinat et al., 2020). The third aspect is the rainfall totals for the storm, which reached $40-50 \mathrm{~mm}$ over wide parts of 
the study region, i.e. 10 times the monthly long-term mean over the study region (Porat et al., 2018).

The aim of this study is to analyse the storm in its seasonal context and to identify the atmospheric conditions that explain its severity. The article is organised as follows. In the next section, we present the data and methods used to analyse the event. Section 3 describes the event through observational evidence. In Sect. 4 we discuss the unique conditions that lead to the severe convection and the sources of moisture for the rain formation in this storm. The main results are summarised in Sect. 5.

\section{Data and methods}

The study area is Israel, with an emphasis given to the Negev Desert and the Judean Desert (Fig. 1). The study period, 2427 April 2018, corresponds to a storm that influenced the EM, in particular on 26 April when the Tzafit flood took place. This storm is one of 12 storms spread over $27 \mathrm{~d}$ ("reference storms", hereafter), with the highest surface runoff observed over the study area in the late spring during 19862018 , based on the hydrometric stations of the Israeli Hydrological Service.

The rainfall data are based on the Israeli Meteorological Service (IMS) rain measuring network and radar data (Porat et al., 2018). The spatial resolution of the radar is $250 \mathrm{~m}$ in the radial direction and $1^{\circ}$ in the azimuthal. These data are rectified to $1 \times 1 \mathrm{~km}$ grid, and its temporal resolution is $5 \mathrm{~min}$. The rain intensity was derived from the radar data (Marra and Morin, 2015).

The atmospheric processes responsible for flash-floodproducing rainstorms combine synoptic and sub-synoptic scales (Bardossy and Filiz, 2005). This also holds specifically for severe convection during the spring over the Negev Desert (Dayan and Morin, 2006; Armon et al., 2019). The data for the synoptic maps, including sea level pressure (SLP) and upper-level fields and geopotential height $(\mathrm{gph})$, were taken from the NCEP/NCAR (National Center for Environmental Prediction/National Center for Atmospheric Research) reanalysis 1 database at $2.5^{\circ} \times 2.5^{\circ}$ spatial resolution (Kalnay et al., 1996; Kistler et al., 2001). The data for the mesoscale maps, including wind, relative and potential vorticity, temperature, and relative humidity, are taken from ERA5 European Centre for Medium-Range Weather Forecasts (ECMWF) reanalysis database (C3S, 2017, https://cds.climate.copernicus. eu/cdsapp\#!/dataset/reanalysis-era5-pressure-levels, last access: 6 July 2019) at $30 \times 30 \mathrm{~km}$ resolution. SLP maps from the two databases for the pertinent region and period were compared for consistency and were found reasonably fit (not shown).

For finer-resolution analysis we used the COSMO regional model (http://www.cosmo-model.org, last access: 20 December 2020), operational at the IMS, covering the east- ern Mediterranean domain $\left(26-36^{\circ} \mathrm{N}, 25-39^{\circ} \mathrm{E}\right.$; Khain et al., 2021) with $2.8 \times 2.8 \mathrm{~km}$ resolution. The model analyses are created by using a continuous assimilation of the radar and rain-gauge composite via latent heat nudging (Stephan et al., 2008, Khain et al., 2020). The boundary and initial conditions are taken from the ECMWF Integrated Forecasting System (IFS) (https://www.ecmwf.int/ en/forecasts/documentation-and-support, last access: 20 December 2020). The COSMO model is based on the primitive thermo-hydrodynamic equations that describe nonhydrostatic compressible flow in a moist atmosphere. Its vertical extension reaches $23.5 \mathrm{~km}(\sim 30 \mathrm{hPa})$ with 60 model levels, including 12 levels between the surface and $900 \mathrm{hPa}$ and 15 levels between 900 and $500 \mathrm{hPa}$, able to capture the planetary boundary layer (PBL) effects (Uzan et al., 2020).

According to the quasi-geostrophic theory, the relative vorticity is a general measure for cyclone intensity and activity (e.g. Holton, 1992). The curvature term dominates near cyclone centres and within meandering flow, whereas the shear term dominates near jets (Uccellini and Kocin, 1987). In the cases analysed here, an upper-level cyclone was found over the Levant or its proximity, accompanied by a southward shift and a weakening of the subtropical jet, and therefore, the curvature vorticity was considered dominant.

Following the above, the vorticity here is approximated by a measure of curvature vorticity (MCV, hereafter), which is calculated on the periphery of the upper-level $(500 \mathrm{hPa})$ cyclones, based on the relation

$\xi_{\mathrm{c}}=V / R$,

where $\xi_{\mathrm{c}}$ is the curvature vorticity, $V$ is the tangential wind speed, and $R$ is the cyclone radius measured on the outermost closed isohypse (when derived with $15 \mathrm{~m}$ intervals). The tangential wind speed was calculated using the geostrophic relation, i.e.

$V \cong g \cdot D /(R \cdot f)$

where $g$ and $f$ are the gravitational acceleration and coriolis parameter, respectively, and $D$ is the depth of the cyclone determined by the difference between its central height and that of the outermost closed isohypse. Inserting $V$ from Eq. (2) in Eq. (1) yields the following:

$\mathrm{MCV}=g \cdot D /\left(R^{2} \cdot f\right)$.

The stability indices were derived from the sounding data of Beit Dagan station, Israel $\left(32.5^{\circ} \mathrm{N}, 34.8^{\circ} \mathrm{E}\right)$, retrieved from the Department of Atmospheric Sciences, The University of Wyoming, at: http://weather.uwyo.edu/upperair/sounding. html (last access: 5 May 2019). These are the following:

- Lifted index (LI; Galway 1956) is the temperature difference between the environment and an air parcel lifted adiabatically from $2 \mathrm{~m}$ above the surface to $500 \mathrm{hPa}$. Negative values indicate instability. 
- Showalter stability index (SI; Showalter, 1953) is similar to the lifted index (LI) but uses a parcel lifted from 850 to $500 \mathrm{hPa}$. As for the LI, negative SI values indicate instability.

- Convective available potential energy (CAPE; Moncrieff and Miller, 1976) is the integrated energy excess of an air parcel lifted adiabatically with respect to its environmental temperature profile. Values in the order of hundreds of joules per kilogram $\left(\mathrm{Jkg}^{-1}\right)$ and more correspond to severe weather.

Maps of the modified $k$-index (MKI) were derived from the ERA5 ECMWF data that cover the Earth on a $30 \mathrm{~km}$ grid. The original $k$-index (KI; Geer 1996), which combines instability and moisture availability, is used to predict severe thunderstorms in the United States. The modified version of Haratz et al. (2010), MKI, is the version adapted for the eastern Mediterranean:

$\mathrm{MKI}=\left(T_{500}-T_{850}\right) \cdot \mathrm{RH}_{850,700}+\mathrm{Td}_{850}-\left(T_{700}-\mathrm{Td}_{700}\right)$,

where $T$ and $\mathrm{Td}$ are temperature and dew point, respectively, RH is relative humidity, and the subscripts refer to the respective pressure level $(\mathrm{hPa})$. The modification gives more weight to the relative humidity at the 850 and $700 \mathrm{hPa}$ levels.

In addition, we also used precipitable water (PW; Liu, 1986), which is the depth of water in the atmospheric column if all the water in that column were precipitated as rain. The values were calculated from the soundings of Beit Dagan. The METEOSAT Second Generation water vapour imageries were retrieved from EUMETSAT data centre (https://navigator.eumetsat.int/product/EO:EUM: DAT:MSG:HRSEVIRI, last access: 1 June 2019) and were used to represent main cloud patterns and mid-level moisture. The infrared (IR) channel was converted to brightness temperatures (Lensky and Rosenfeld, 2008) and used for estimating the height of the cloud tops.

Air back trajectories for detecting moisture transport were retrieved from the site of NOAA HYSPLIT model (Stein et al., 2015, https://www.ready.noaa.gov/HYSPLIT.php, last access: 1 April 2019) Global Data Assimilation System (GDAS; $1^{\circ} \times 1^{\circ}$ resolution, on pressure levels), which is used by the NCEP Global Forecast System (GFS) model to place observations into a gridded model space for initialising weather forecasts with observed data. The "model vertical velocity" (derived from the gridded data) option was used.

\section{Observational analysis}

\subsection{Synoptic evolution}

During 25-27 April 2018 the Levant was dominated by an upper-level closed cyclone, accompanied by a lower-level cyclone, located east of Israel (see Fig. 2).
Prior to the storm, on 24 April 2018, the lower levels were influenced by a RST. The axis of the RST was located east of the Levant, enclosing a shallow cyclone with a central pressure of $1008 \mathrm{hPa}$ over north-western Saudi Arabia (see Fig. 2a), transporting warm and dry air from the east toward the Levant. At the $500 \mathrm{hPa}$ level, a closed cyclone was approaching the region from the central Mediterranean. During 25 April the upper-level cyclone slowed its progress, from $\sim 9$ to $\sim 4 \mathrm{~m} \mathrm{~s}^{-1}$, while arriving to the Egyptian coast (see Fig. 3). The surface shallow cyclone deepened, attaining a central pressure of $1000 \mathrm{hPa}$, and moved northward, to Iraq, resembling the Syrian Low (Kahana et al., 2002). The winds over the south-eastern Mediterranean backed to north-westerly, hence advecting moist air from the Mediterranean inland, to central and southern Israel. The rain in Israel started on 25 April and stopped on 27 April (Porat et al., 2018). The spatial distribution of the rain during the entire storm is shown in Fig. 1. The maximum rainfall occurred east of the water divide of the Negev Mountains, and the second most intense one was found in the Jordan Valley, $200 \mathrm{~m}$ b.s.1 (below sea level).

During the following day, 26 April, the upper-level cyclone continued its slow eastward progression (Figs. $2 \mathrm{c}$ and 3 ). The weakening of the horizontal pressure gradient at the surface on 27 April (compare Fig. 2c and d), in tandem with a flattening of the $500 \mathrm{hPa}$ cyclone and its movement further eastward, led to the cessation of the stormy weather over Israel.

The upper-level cyclone, besides its geopotential depth (up to $100 \mathrm{~m}$; Fig. 2), was accompanied by an isolated PV maximum, as seen in the $300 \mathrm{hPa}$ map for 26 April 00:00 UTC (Fig. 4), indicating its being a cut-off low (Hoskins et al., 1985). Moreover, its evolution took place south-east of an upper-level blocking high that covered eastern Europe during 24 and 25 April, as can be inferred from the PV distribution seen in Fig. 5a-c. The interaction between the blocking high and the cut-off low and its contribution to the slowing of the cut-off low when approaching the Levant are elaborated in Sect. 4 below.

The synoptic-climatologic background for this storm is compared with the other rainstorms, comprising the set of 12 "reference storms", all of them occurring in the late spring and producing considerable surface runoff over the study area (see Sect. 2 above). In all of the reference storms except one, upper-level closed cyclones were found over the EM or the Levant. The cyclones' depth varied between 10 and $130 \mathrm{~m}$, with an average of $52 \mathrm{~m}$, and their radii ranged between 200 and $900 \mathrm{~km}$, with an average of $600 \mathrm{~km}$ (Table 1). The MCV for the various days belonging to the reference storms varied between 0.8 and $3.8 \times 10^{5} \mathrm{~s}^{-1}$, with an average of $2.3 \times 10^{5} \mathrm{~s}^{-1}$. The maximum value was observed during the present storm. The MCV for the present storm was approximately one-half that of the respective maximum relative vorticity (Fig. 3) presumably due to the spatial smoothing implied by the derivation method of the MCV. 


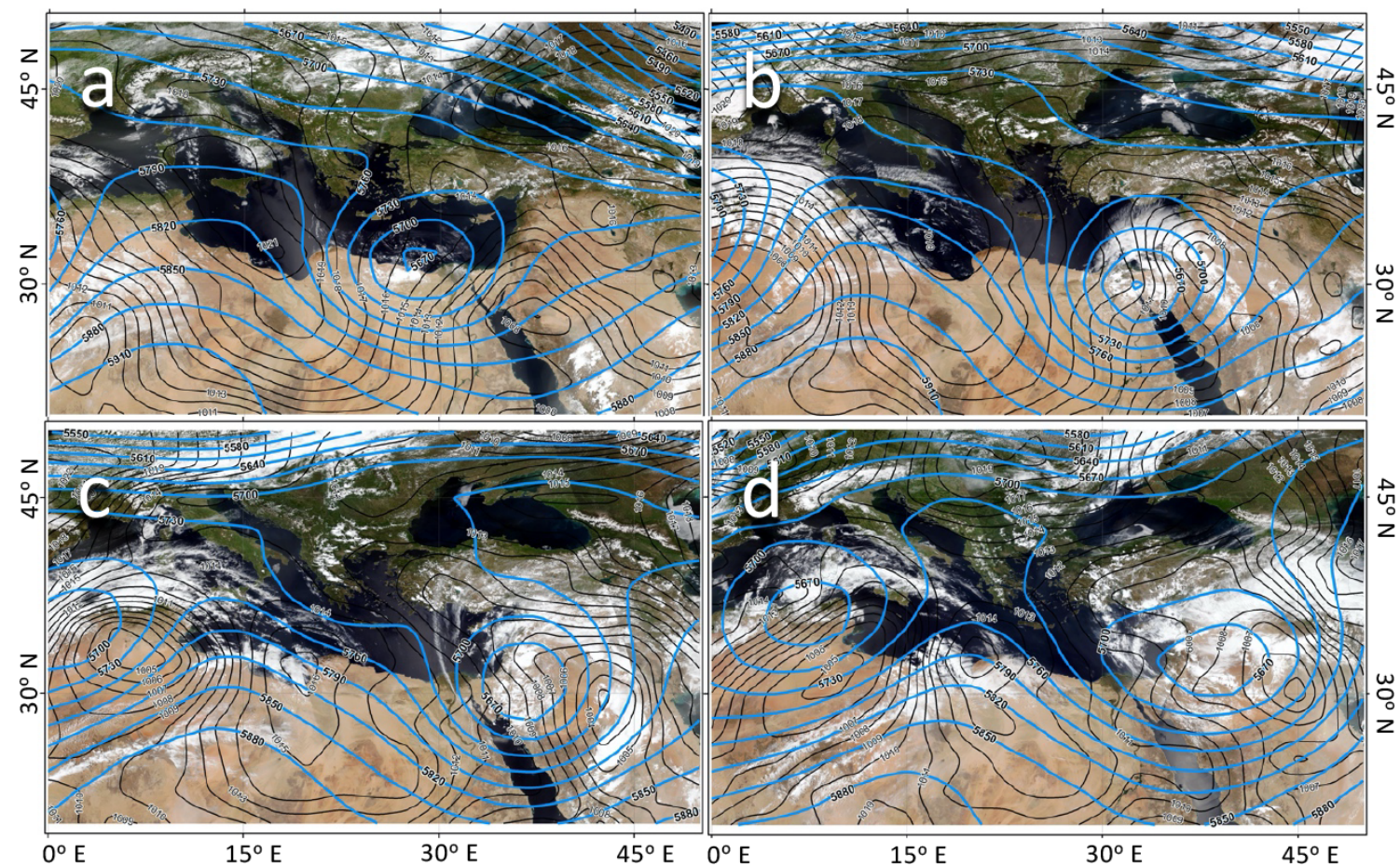

Figure 2. Geopotential height (GPH) (blue lines) at $500 \mathrm{hPa}(\mathrm{m})$ and SLP (hPa) (black lines) projected on MODIS imagery, in $24 \mathrm{~h}$ intervals, for 24-27 April 2018 at 12:00 UTC (a-d).

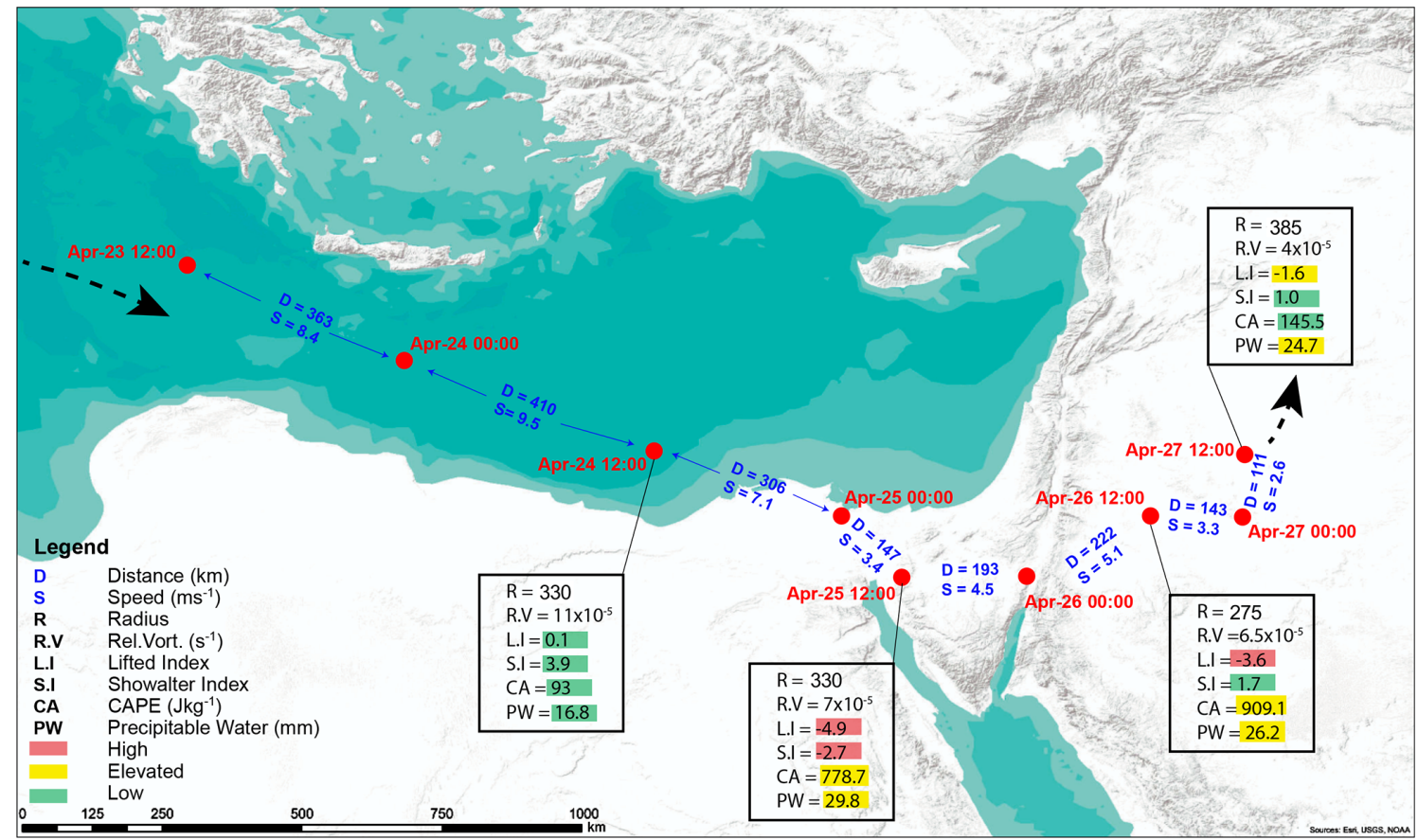

Figure 3. Track of the upper-level cyclone (500 hPa GPH) during 24-27 April 2018 in 12 h intervals. The instantaneous speed (m s $\left.{ }^{-1}\right)$ and distance $(\mathrm{km})$ spanned during each increment are denoted by $S$ and $D$, respectively. For each $24 \mathrm{~h}$ increment, the radius of the upper-level low $(\mathrm{km})$, the maximum relative vorticity $\left(\mathrm{s}^{-1}\right)$, the precipitable water (PW, in $\mathrm{mm}$ ) and three thermodynamic indices (LI, SI and CA) as calculated from the sounding of Beit Dagan are specified. "High", "Elevated" and "Low" values of the indices are highlighted in red, yellow and green, respectively. 


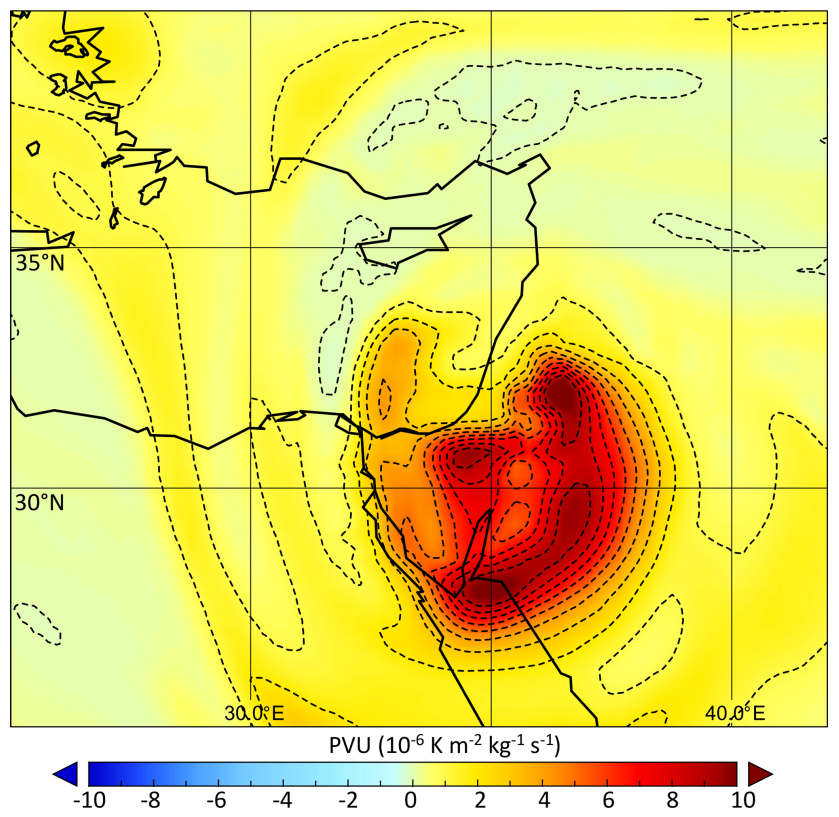

Figure 4. Potential vorticity units (PVU) at $300 \mathrm{hPa}$ for 26 April 00:00 UTC, taken from ERA-5 at $30 \mathrm{~km}$ spatial resolution. The major feature is a closed positive anomaly (with maximum of $\mathrm{K} \mathrm{m}^{-2} \mathrm{~kg}^{-1} \mathrm{~s}^{-1}$ ), corresponding to a cut-off low centred over north-western Saudi Arabia.

During the approach of the cut-off low, the atmosphere over the study region became more and more unstable. Figure 3 shows the values of leading instability indices (specified in Sect. 2) derived from Beit Dagan soundings in $24 \mathrm{~h}$ increments. They reflect a gradual increase toward 25 April 12:00 UTC when the upper-level cyclone approached the Sinai Peninsula. At that time, the value of CAPE was $779 \mathrm{~J} \mathrm{~kg}^{-1}$, of LI $-4.9 \mathrm{~K}$ and of SI $-2.7 \mathrm{~K}$, indicating a potential for thunderstorms. On 26 April, the CAPE rose to $909 \mathrm{~J} \mathrm{~kg}^{-1}$.

The transition from the dry conditions that persisted on 24 April to the wet conditions that developed toward 25 April is manifested by a sharp increase in the precipitable water (PW) in Beit Dagan, from $17 \mathrm{~mm}$ (24 April 12:00 UTC) to $30 \mathrm{~mm}$ on 25 April 12:00 UTC ( $27 \mathrm{~mm}$ on 26 April). The moisture increased presumably due to the north-westerly wind, as evidenced by the air trajectories entering the study area at the heights of 600 and $1000 \mathrm{~m}$. The trajectory that entered the region at $1400 \mathrm{~m}$ originated from Iraq, entered northern Israel from the east and, after turning cyclonically, penetrated the Negev Desert from the north-west (Fig. 6). The signature of the segment of the latter trajectory, extending from Iraq toward northern Israel, is clearly seen as a bright band in the satellite imagery of the water vapour channel for 25 April 21:00 UTC (12 h prior to Tzafit flood; Fig. 7), reflecting a moisture strip.
Table 1. Depth, radius and the measure of curvature vorticity (MCV) of the $500 \mathrm{hPa}$ cyclones for the $27 \mathrm{~d}$, in which the highest surface runoff was observed over the study area in the late spring during the period 1986-2018 (the reference storms). Note that in 24 of the days an upper-level cyclone was identified.

\begin{tabular}{|c|c|c|c|c|}
\hline $\begin{array}{r}\text { Storm } \\
\text { no. }\end{array}$ & Date & $\begin{array}{r}\text { GPH } \\
\text { depth } \\
(\mathrm{m})\end{array}$ & $\begin{array}{r}\text { Radius } \\
(\mathrm{km})\end{array}$ & $\begin{array}{r}\mathrm{MCV} \\
\left(\times 10^{5} \mathrm{~s}^{-1}\right)\end{array}$ \\
\hline 1 & 2 Apr 1986 & 70 & 650 & 2.3 \\
\hline 1 & 3 Apr 1986 & 25 & 400 & 2.1 \\
\hline 2 & 8 Apr 1986 & 45 & 650 & 1.4 \\
\hline 2 & 9 Apr 1986 & 45 & 900 & 0.8 \\
\hline 3 & 14 Мay 1997 & no & no & \\
\hline 3 & 15 May 1997 & no & no & \\
\hline 4 & 4 Apr 2001 & 130 & 900 & 2.2 \\
\hline 5 & 30 Apr 2001 & 15 & 250 & 3.3 \\
\hline 5 & 1 May 2001 & 25 & 350 & 2.8 \\
\hline 5 & 2 May 2001 & 90 & 850 & 1.7 \\
\hline 5 & 3 May 2001 & 90 & 750 & 2.2 \\
\hline 6 & 12 May 2007 & 50 & 580 & 2.0 \\
\hline 7 & 4 May 2011 & 70 & 900 & 1.2 \\
\hline 7 & 5 May 2011 & 20 & 280 & 3.5 \\
\hline 8 & 7 May 2014 & 15 & 330 & 1.9 \\
\hline 8 & 8 May 2014 & 50 & 550 & 2.2 \\
\hline 9 & 11 May 2014 & 35 & 500 & 1.9 \\
\hline 9 & 12 May 2014 & 10 & 200 & 3.4 \\
\hline 10 & 16 Apr 2015 & 30 & 350 & 3.3 \\
\hline 11 & 10 Apr 2016 & no & no & \\
\hline 11 & 11 Apr 2016 & 45 & 550 & 2.0 \\
\hline 11 & 12 Apr 2016 & 50 & 650 & 1.6 \\
\hline 11 & 13 Apr 2016 & 40 & 550 & 1.8 \\
\hline 11 & 14 Apr 2016 & 45 & 520 & 2.3 \\
\hline 12 & 25 Apr 2018 & 100 & 600 & 3.8 \\
\hline 12 & 26 Apr 2018 & 80 & 550 & 3.6 \\
\hline 12 & 27 Apr 2018 & 70 & 600 & 2.6 \\
\hline
\end{tabular}

\subsection{The 26 April main rain episodes}

In the early morning of 26 April, the northern part of Israel was the only one receiving rain, mostly moderate, originating from stratified cloudiness (based on hourly radar images, not shown). After several hours of fair weather, during the noon hours, three major rain centres developed. Figure 8 shows the three centres as reflected by two observational means, i.e. satellite IR and radar imageries, and two diagnostic tools, vorticity field at a $30 \mathrm{~km}$ resolution and MKI at a $2.8 \mathrm{~km}$ resolution.

The first rain centre, composed of several cells, was most active between 09:00 and 10:30 UTC and produced the Tzafit flood. This centre yielded up to $50 \mathrm{~mm}$ rainfall, with a maximum intensity of $180 \mathrm{~mm} \mathrm{~h}^{-1}$ based on 5 min averages of radar measurements. This intensity has a return period of $>75$ years for that particular region (Rinat et al., 2020). This centre can be noted in the radar image for 09:00 UTC (Fig. 8c). Its evolution is represented by a series of radar im- 


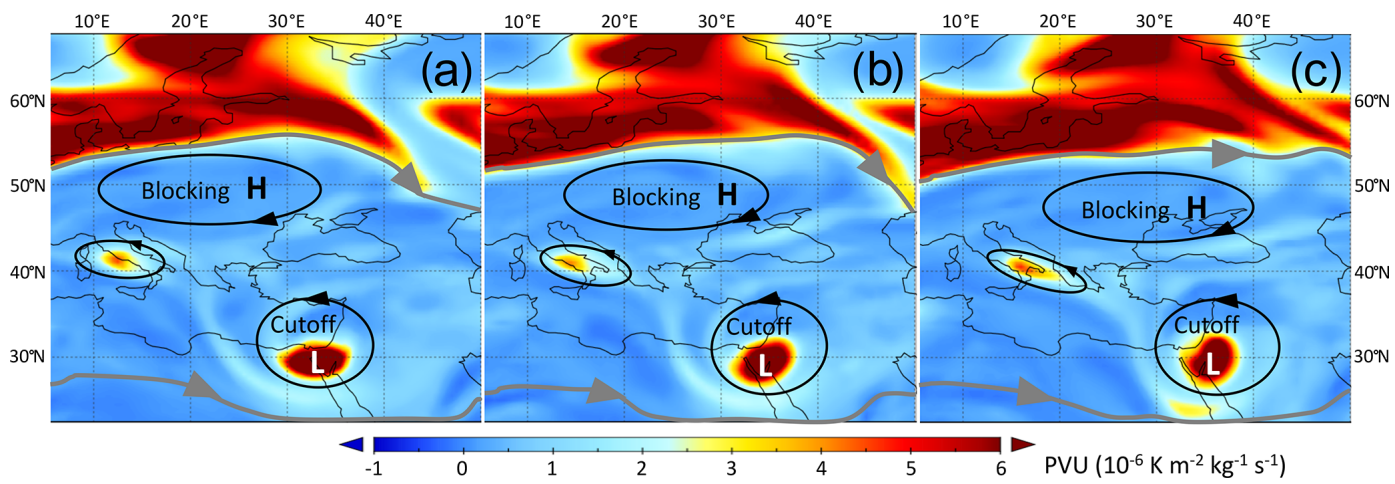

Figure 5. PV distribution at $300 \mathrm{hPa}$ starting on 25 April 2018 at 12:00 UTC in $6 \mathrm{~h}$ intervals, covering Europe and the Mediterranean Basin, on which a conceptual sketch of a dipole-type block (following Yamazaki and Itoh, 2013) is superposed. A cut-off low is seen over the south-eastern Mediterranean and a blocking high over eastern Europe, forming a dipole. The arrows show the induced flow of each of the vortices.

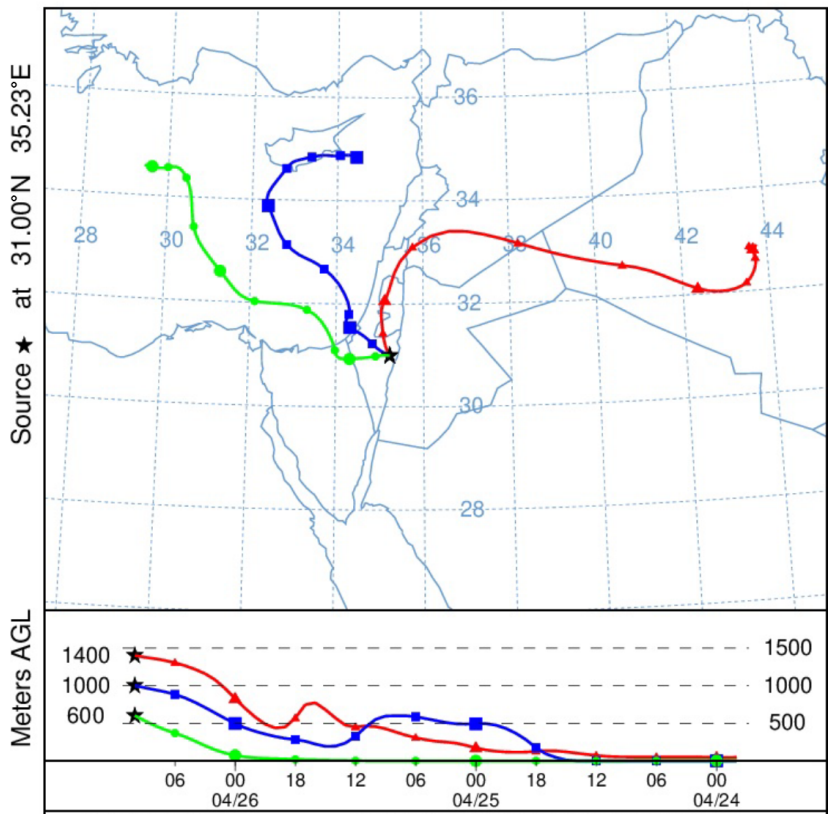

Figure 6. The $60 \mathrm{~h}$ back trajectory of the air mass reaching the Tzafit Basin on 26 April 2018 at 10:00 UTC at heights of 600, 1000 and $1400 \mathrm{~m}$ a.g.l. (above ground level).

ages (Fig. 9) showing that it resulted from the passage of successive three rain cells that crossed the region from north to south with an average speed of $12 \mathrm{~m} \mathrm{~s}^{-1}$. Figure $8 \mathrm{e}$ indicates the existence of a positive vorticity anomaly at the $500 \mathrm{hPa}$ level over the Dead Sea (denoted in blue, north-east of Tzafit) with $\sim 50 \mathrm{~km}$ diameter at 09:00 UTC, implying that positive vorticity advection existed over Tzafit via the north-easterly flow at that level.

Later on, around 12:00 UTC, another rain centre developed in the Jordan Valley (near the city of Beit Shean; $32.5^{\circ} \mathrm{N}, 35.5^{\circ} \mathrm{E}$ ) in northern Israel, in the form of a cloud line, as reflected by the satellite and radar images (Fig. 10a).

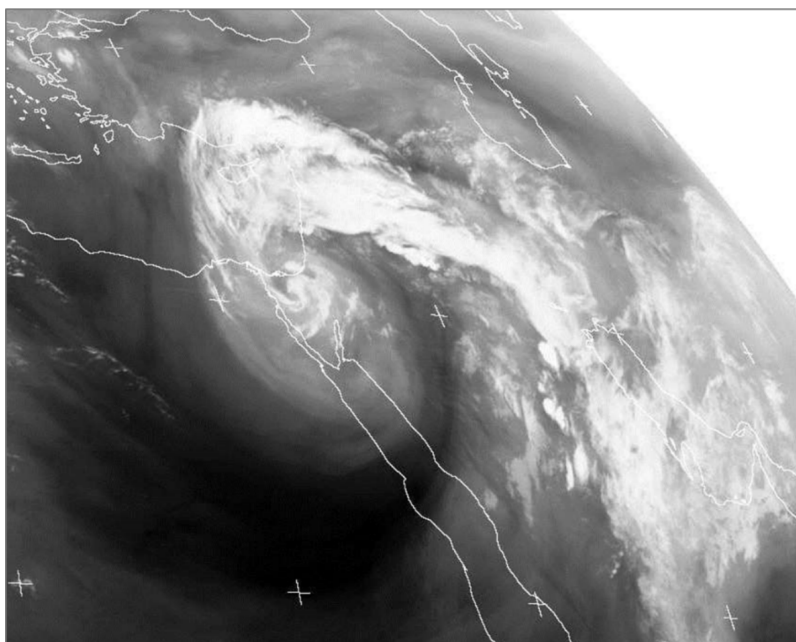

Figure 7. METEOSAT water vapour channel $6(6.85-7.85 \mu \mathrm{m}) \mathrm{im}$ agery from 25 April 2018 21:00 UTC showing the cloud strip entering Israel from the east and the vortex over the south-eastern Mediterranean.

This cell yielded rainfall of $30-45 \mathrm{~mm}$ with a maximum of $72 \mathrm{~mm}$ (record breaking since start of record at 1943). The maximal $10 \mathrm{~min}$ averaged rate was $116 \mathrm{~mm} \mathrm{~h}^{-1}$, having a return period of 100 years (Porat et al., 2018). During this rain episode, a lower-level trough extended toward the region from the south-east (i.e. Jordan; Fig. 10b). Its curved shape and orientation (denoted by a purple line) resemble these of the cloud line. This system crossed the region southward at an average speed of $7 \mathrm{~m} \mathrm{~s}^{-1}$. The rain in Beit Shean can also be attributed to positive vorticity advection at the $500 \mathrm{hPa}$ level caused by north-easterly winds ahead of a pronounced core of a positive vorticity anomaly of $>2 \times 10^{-4} \mathrm{~s}^{-1}$ and $\sim 100 \mathrm{~km}$ diameter, centred over western Jordan $\left(32.3^{\circ} \mathrm{N}, 36.7^{\circ} \mathrm{E}\right)$. This core approached the region (red point in Fig. 8f) from the east and was one of the 

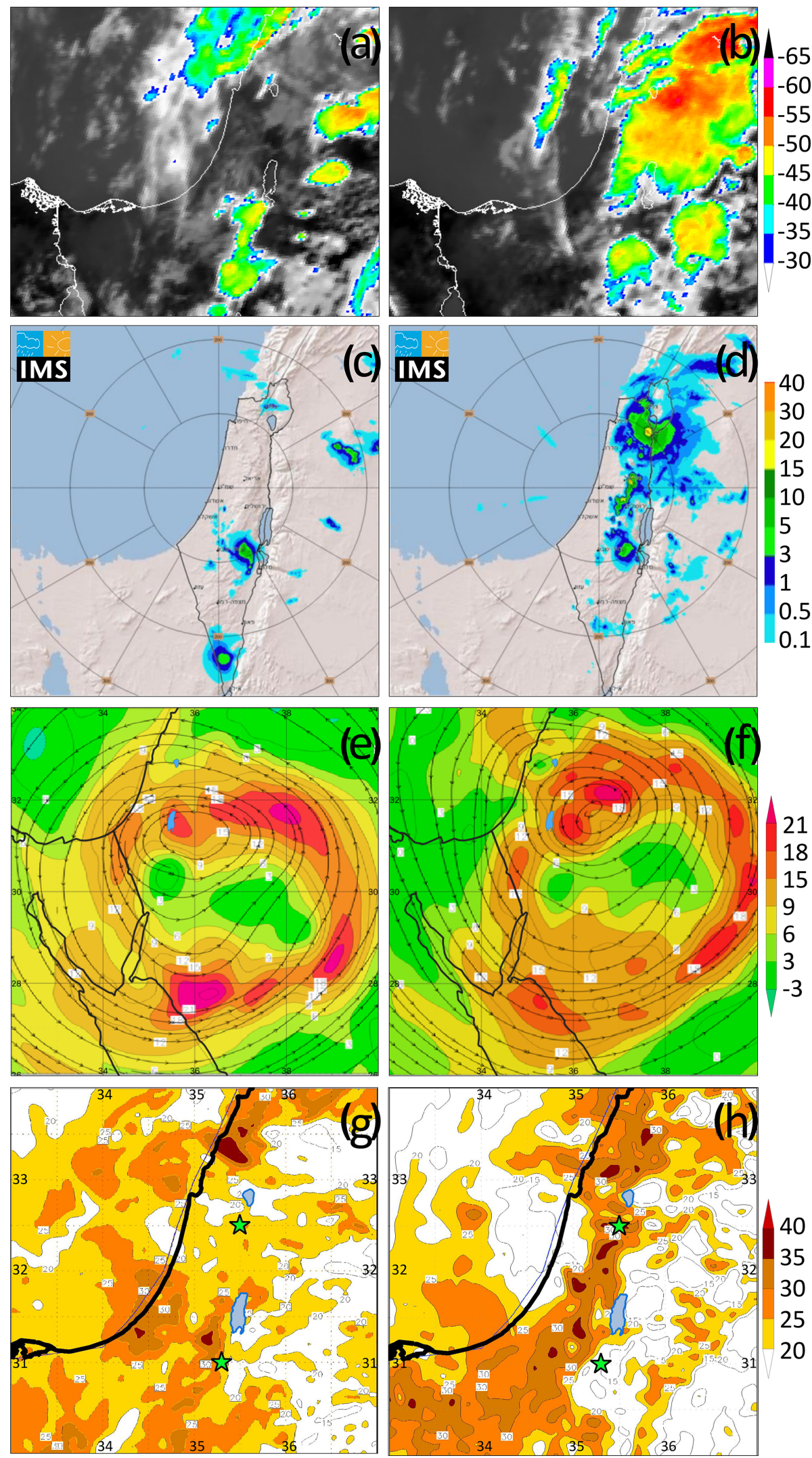

Figure 8. The 26 April imageries for 09:00 (a, c, e, g) and 12:00 UTC (b, d, f, h) corresponding to the major rain centres including Meteosat Second Generation (MSG) IR images $(\mathbf{a}, \mathbf{b}), 1 \mathrm{~h}$ forward integration radar $\left(\mathrm{mm} \mathrm{h}^{-1}\right)$ images $(\mathbf{c}, \mathbf{d})$, relative vorticity $\left(\mathrm{s}^{-1} \times 10^{5}\right)$ and streamlines at $500 \mathrm{hPa}(\mathbf{e}, \mathbf{f})$, and $\mathrm{MKI}\left({ }^{\circ} \mathrm{C}\right)(\mathbf{g}, \mathbf{h})$. Panels $(\mathbf{e})$ and $(\mathbf{f})$ are based on ERA5 data at $30 \mathrm{~km}$ spatial resolution, and $(\mathbf{g})$ and $(\mathbf{h})$ are based on the COSMO model at $2.8 \mathrm{~km}$ spatial resolution. 


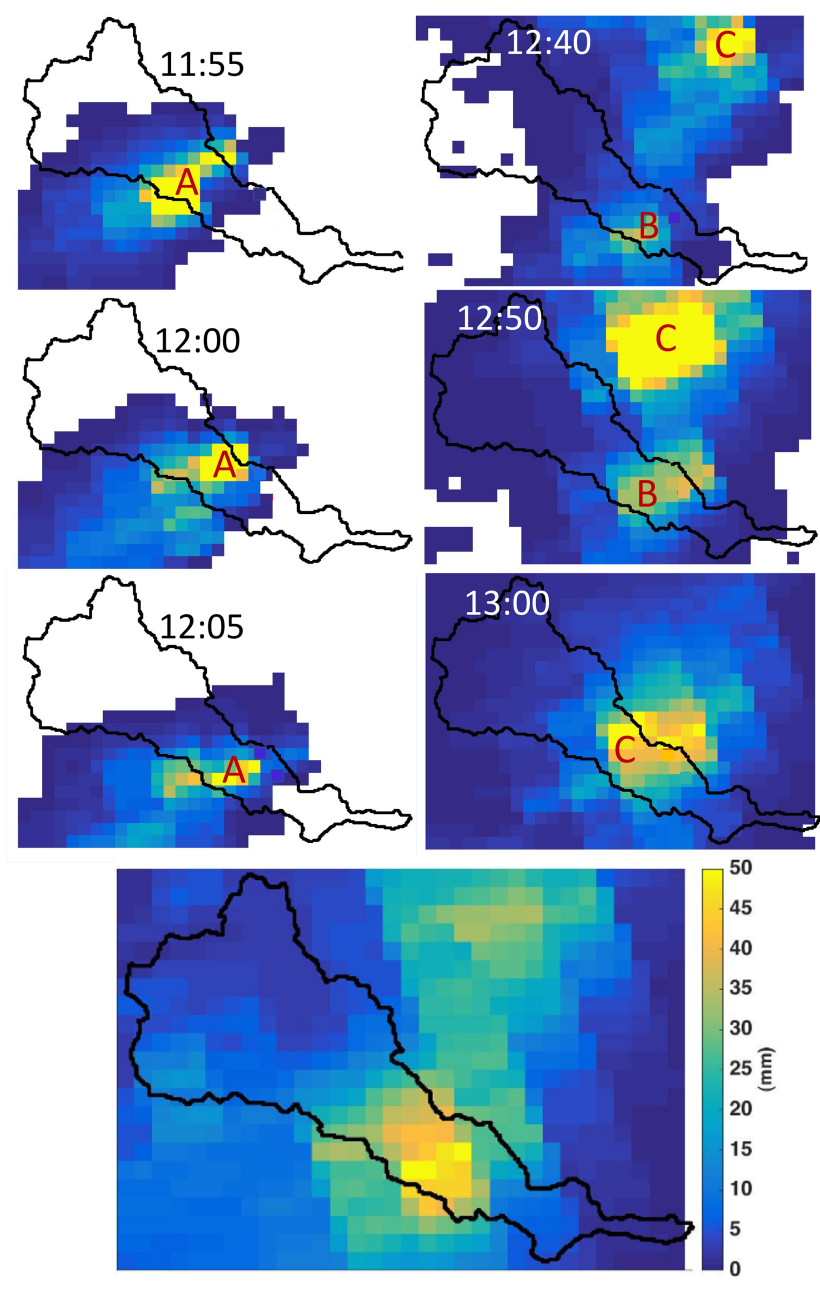

Figure 9. (a). A series of radar images indicating the progression of rain cells (denoted $\mathrm{A}, \mathrm{B}$ and $\mathrm{C}$ ) that crossed the Tzafit Basin ( 1 pixel is equivalent to $0.25 \mathrm{~km}^{2}$ ). The time notations refer to the summer clock (LST; UTC $+3 \mathrm{~h}$ ). The units are millimetres per hour $\left(\mathrm{mm} \mathrm{h}^{-1}\right)$, based on the conversion method of Mara and Morin (2015). (b) Total rain amount accumulated between 11:40 and 13:40 LST. Note the meridional orientation of the rainfall maximum, pointing at the "training effect" (with the courtesy of Yair Rinat).

two vorticity centres that constituted the synoptic-scale cutoff low at 12:00 UTC (Fig. 2).

The third rain centre started to develop at 12:00 UTC and lasted $\sim 2 \mathrm{~h}$. This centre was aligned with the water divide of the Samarian and Judean Mountains and its adjacent slopes facing the north-westerly winds (Fig. 8b and d), and therefore it can be considered to be forced by orography. This rain centre yielded $30-35 \mathrm{~mm}$ with a $10 \mathrm{~min}$ averaged maximum rate of $100 \mathrm{~mm} \mathrm{~h}^{-1}$ in Jerusalem, having a return period of 100 years (Porat et al., 2018). In the late afternoon, southern Israel was still under precipitative cloudiness (not shown).

Vertical profiles for two major rain centres, in Tzafit (Fig. 11a) and near Beit Shean (Fig. 11b), derived from the fine-resolution data of the COSMO model (described in Sect. 2). Each one includes the temperature, dew point and a line denoting the cooling of an air parcel that is lifted diabatically from the surface. Both reflect moist and conditionally unstable conditions. The lifted air parcel in both of them is warmer by $\sim 5 \mathrm{~K}$ than its surrounding temperatures within layers several kilometres wide. This implies that in both rain events the ascending air currents within the rain cells were subjected to intense buoyancy forces and, hence, had high vertical speeds. Accordingly, the CAPE and the MKI over their locations at the time of their occurrences exceeded $1200 \mathrm{~J} \mathrm{~kg}^{-1}$ and $30 \mathrm{~K}$ (1740 in Beit Shean), respectively, values that are favourable for thunderstorms. Moreover, the tops of clouds of the three precipitative centres reached $-50^{\circ} \mathrm{C}$. According to the temperature profiles over the study region during the storm, this implies that these cloud tops exceeded an elevation of $9000 \mathrm{~m}$.

\section{Discussion}

Precipitation extremes in the Mediterranean Basin are usually induced by large-scale atmospheric circulation, namely low-pressure systems with large pressure gradients (Jacobeit et al., 2017). Therefore, the analysis starts from the synoptic system with which this storm was associated, namely the upper level cut-off low. This cut-off low entered the EM from the north-west, deepened and crossed the Levant at $30^{\circ} \mathrm{N}$ latitude (Figs. 2 and 3). The maximum vorticity measured in $500 \mathrm{hPa}$ level was $>7.2 \times 10^{-5} \mathrm{~s}^{-1}$ which is comparable to the value of $5 \times 10^{-5} \mathrm{~s}^{-1}$ at the same level found by Flocas et al. (2001) for the winter season in the Mediterranean. Apparently, this implies that the synoptic factor was dominant in rain production. However, the convective nature of the rain and its spotty distribution were demonstrated by radar images (Fig. 8c and d) and were even reflected in the rain map of the entire storm (Fig. 1).

Following the quasi-geostrophic approach, most convective outbreaks occur in broad south-westerly flow aloft and ahead of an approaching trough (Doswell, 1987). On 26 April, under the north-westerly flow behind the upper-level cyclonic system, its direct dynamic supporting effect on rain formation is expected to be weak, or even negative (Fig. 2c). At this sector, negative upper-level vorticity advection and lower-level cold advection are expected, both implying subsidence in the mid-levels. Inspection of the lower-level temperature and wind fields (not shown) indicate that at that stage, the cold core associated with the upper-level cyclone was centred over the Negev Desert. The lower-level winds over the study region were parallel to the isotherms so that no temperature advection existed. A similar configuration existed with respect to the upper-level vorticity field, implying that vorticity advection on the synoptic scale also did not take place there. Moreover, the omega field at the mid-levels in the synoptic scale over the region was near zero. The above im- 

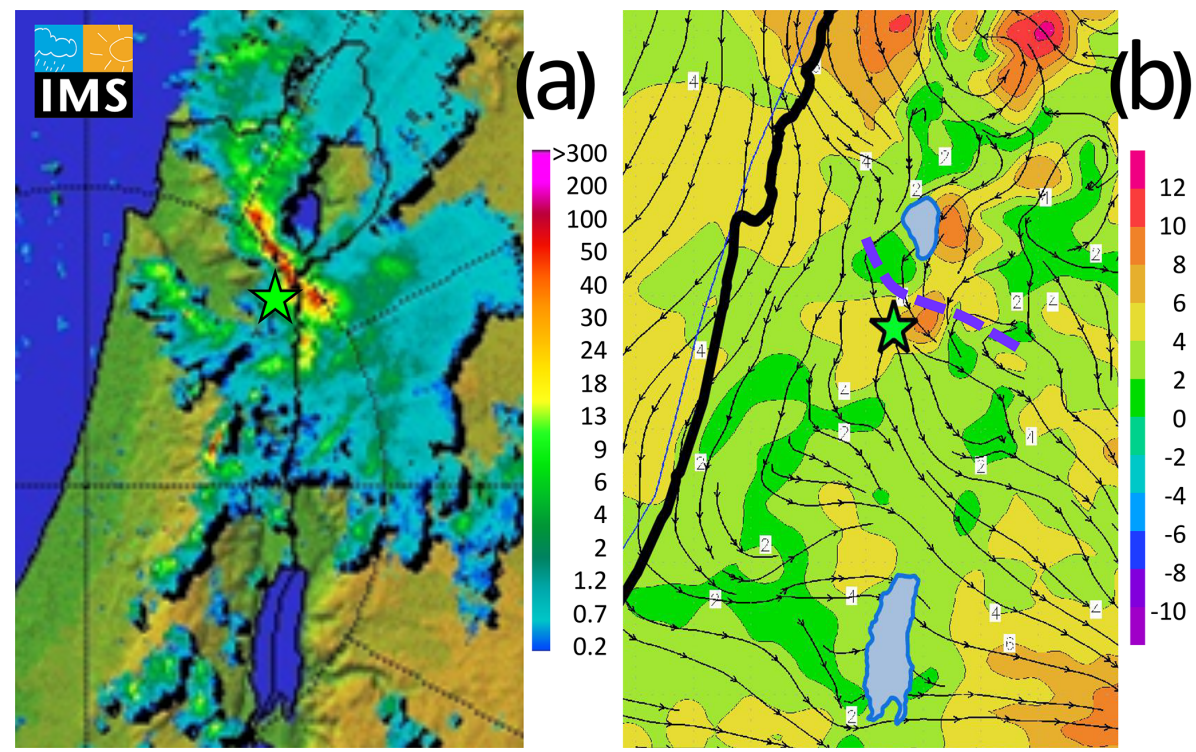

Figure 10. (a) Radar image (in $\mathrm{mm} \mathrm{h}^{-1}$ units) indicating the precipitative element that crossed Beit Shean (Lake Kinneret, seen north-east of it). Note that the maximum rain intensities reach $50 \mathrm{~mm} \mathrm{~h}^{-1}$. (b) The $850 \mathrm{hPa}$ streamlines and wind speed, with a purple curved line denoting the trough line. Beit Shean is denoted by a green star in both parts. The radar image is from 12:20 UTC and the wind map from 12:00 UTC.
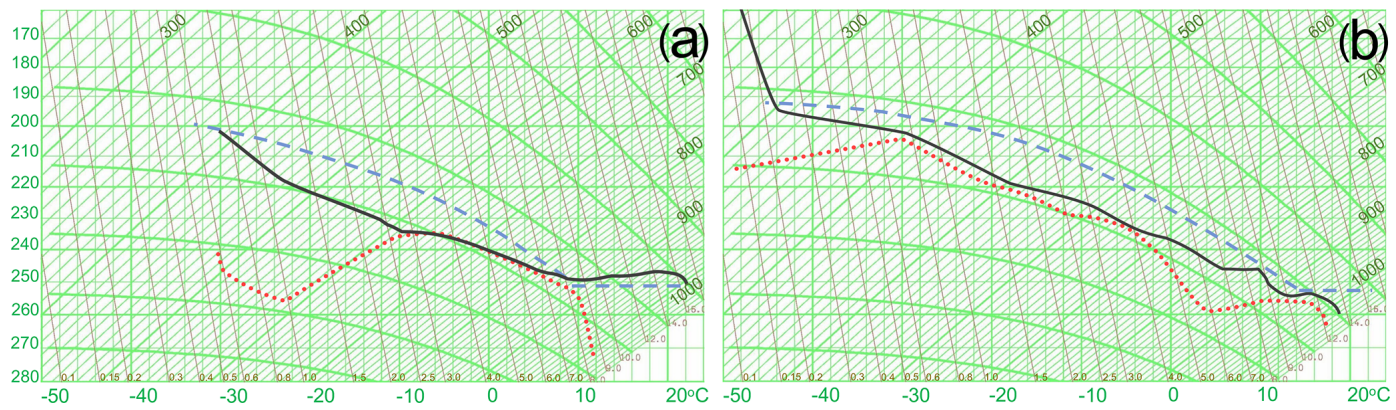

Figure 11. Vertical profiles for (a) Tzafit (26 April 2018 at 09:30 UTC) and (b) Beit Shean (26 April 2018 at 12:30 UTC). The black lines denote temperature, the dotted red lines dew point and the dashed blue lines the adiabatic cooling of air parcels ascending from the surface.

plies that the synoptic-scale dynamics did not have a direct effect on the rain formation on that day.

The major synoptic factor that directly contributed to the rain formation in this storm is the wind. One implication is the onshore moisture transport, accompanied by an uplift imparted by its encounter with the coastline and later on with the mountain ridges. The other is the upper-level cold advection, leading to thermal instability, which is further elaborated below. Actually, only a small fraction of the rainfall in this storm was orographic (over the Judean Mountains), whereas the majority of the rain was observed far from the coastline and beyond the water divides of the mountain ridges (Fig. 1, note the divide line).

The mesoscale analysis performed exposes several uplifting mechanisms not captured by the synoptic-scale data, which can explain the occurrence of the Tzafit and Beit Shean major rain centres. Each of these two centres was found to be associated with a positive vorticity advection ahead of a positive anomaly at the $500 \mathrm{hPa}$ level in the ERA5 maps with $30 \times 30 \mathrm{~km}$ resolution. The first anomaly was located east of Tzafit at 09:00 UTC, prior to the rain there (Fig. 8e), and the other east of Beit Shean at 12:00 UTC when the rain system started its movement southward over that region (Fig. 8f). The third mechanism was identified in the wind field of the COSMO data at the $925 \mathrm{hPa}$ level in the form of a lower-level trough (Sect. 3.2, Fig. 10b) with shape, orientation and progression velocity similar to these of the rain producing system (Fig. 10a).

Despite the affinity of the Mediterranean cyclones to midlatitude cyclones due to the limited moisture sources in the Mediterranean Basin (Ziv et al., 2010), the rain they produce highly depends on moisture supply rather than on the presence of conveyor belts or front. The lower-level system in the storm analysed here can be considered a Syrian Low (Kahana et al., 2002; see Sect. 1 above), which belongs to the Mediterranean cyclones. The Syrian Low resembles the "deep low to 
the east", which is one of the seven types of Cyprus lows defined by Alpert et al. (2004). Saaroni et al. (2010) showed that most of the rain associated with the deep low to the east is distributed over the coastal regions and the western slopes of the Judean Mountains, facing the offshore north-westerly winds blowing from the Mediterranean. This indicates that the Judean Mountains, extending up to $800-1000 \mathrm{~m}$, block effectively the moisture, which is presumably concentrated in the lower levels. The heavy rains that were observed inland in this storm and the signature of non-orographic major rain cells in the rain maps indicate that the moisture sources were not limited to the lower levels. The presence of moisture at the mid-levels is deduced from the back trajectory arriving at Tzafit at the time when the flood occurred (Fig. 6). This shows a band of mid-level moist air that originated east of the Levant, turned cyclonically around the cyclone centre and entered the region from the west.

In the EM, rains associated with Mediterranean cyclones, as in the case studied here, are convective in nature. In the winter season, cold air originating from southern Europe moves over the warmer Mediterranean water and becomes unstable before entering Israel (Shay-El and Alpert, 1991). In the late spring, Europe becomes warmer, whereas the Mediterranean remains cool due to its lagged response to the annual cycle so that the passage of a Cyprus Low over the EM does not necessarily lead to instability. In the case studied here, the instability can be attributed to a negative temperature anomaly at the upper levels (in the order of $-4 \mathrm{~K}$ in $500 \mathrm{hPa}$, not shown) that covered the southern Levant as a part of the cut-off low. A tendency of the rain in the Negev Desert to be convective, especially in the transition seasons, has been noted previously. Sharon (1978) and Dayan and Sharon (1980) pointed at a gradual increase in the proportion of localised showers in the transition from the Mediterranean part of Israel further into the more arid south. Systematic evidence for this tendency is well reflected in the low spatial correlation obtained among several rain stations for April over southern Israel (Kutiel, 1982).

The considerable rainfall in the three major rain centres described above can be explained by several factors:

a. The first is the high degree of instability, originated by the upper-level cold air, which was further enhanced by the intense solar radiation prior to the three rain events, as implied by the date, latitude and the clear sky (Fig. 8a). This effect is reflected by the MKI maps (Fig. 8g and h) showing much higher values inland compared to these along the coastal region $\left(35^{\circ} \mathrm{C}\right.$ in Tzafit Basin compared to $13.2^{\circ} \mathrm{C}$ in Beit Dagan) and by a gradual increase in CAPE during the morning hours (not shown), up to $1740 \mathrm{~J} \mathrm{~kg}^{-1}$ in Beit Shean. This factor can explain the extreme rain intensities observed in the three major rain centres.

b. The high elevation of the cloud tops in the three major rain centres, exceeding $9000 \mathrm{~m}$ a.s.l., is $2500 \mathrm{~m}$ higher than that typifying the tops of the winter thunderclouds in Israel (Altaratz et al., 2001).

c. For the convective rains observed over the Judean Mountains during the noon hours, a central factor is orography.

d. The above three factors led to extreme and exceptional instantaneous rain rates, exceeding a 75-year return period in Tzafit and a 100-year return period in the other two major rain centres.

e. A significant contribution to the high rainfall in the Tzafit Basin can be attributed to the propagation vector (train effect), i.e. repeated areas of rain cells that move over the same region in a relatively short period of time, which may cause flash flooding (e.g. Cordifi et al., 1996).

f. An optional factor that may explain the repetitive formation of rain cells north of Tzafit is a mountain-valleycirculation (anabatic) uplift over the eastern slopes of the ridge that extends from the Judean Mountains southward (Fig. 1). This could be expected in light of the clear skies prior to this event, but we did not find any signature in the output of the COSMO model.

g. The high rainfall in Beit Shean can be partly explained by the slow movement of the rain system, a speed of $7 \mathrm{~m} \mathrm{~s}^{-1}$.

Beyond the major direct contribution of the instability, moisture supply and topographic features to the evolution of the major rain cells, the role of the synoptic factor, namely the cut-off low, can be considered a supportive background for these effects. The impact of cut-off lows on rainstorms over the Mediterranean has also been shown by Porcu et al. (2007) and by Fragoso and Tildes Gomes, 2008 (Sect. 1). This is in line with the fact that 11 out of the 12 reference rainstorms that occurred over the study region in the late spring were accompanied by upper-level closed cyclones.

The slow eastward propagation of the cut-off low exacerbated the severity of the storm by extending its duration. The typical translation speed of Mediterranean cyclones is $5-10 \mathrm{~m} \mathrm{~s}^{-1}$ (Alpert and Ziv, 1989). The speed of the cutoff low was $7-9 \mathrm{~m} \mathrm{~s}^{-1}$ when moving along the Libyan coast but slowed down to $3-5 \mathrm{~m} \mathrm{~s}^{-1}$ when approaching the EM (Fig. 3). The series of $300 \mathrm{hPa}$ PV maps (Fig. 5a-c), on which a conceptual sketch of a dipole type is superposed, consisting of a blocking high located north of the cut-off low, follows Yamazaki and Itoh (2013). These charts show a lobe of negative PV (blue) over the Balkans, north of the cut-off low, lingering over the Nile Delta. The power of PV maps stems from the feature of PV anomalies (in the spatial sense) to induce circular flow out of their boundaries, i.e. cyclonic for positive and anticyclonic for negative. The negative anomaly centred over eastern Europe exerted an anticyclonic flow over 
the region, which produced easterly winds south of it, including the Levant, where the positive anomaly (with which the cut-off low was associated) was located. At the same time, the positive anomaly over the southern Levant exerted a cyclonic flow around it, including easterly winds over eastern Europe, where the negative anomaly was positioned. This is most clearly demonstrated in Fig. 5c. The outcome of the superposed effects is that both anomalies were subjected to forces acting against the mid-latitude westerlies. This explains the slow progression of the cut-off low upon reaching the Levant.

\section{Summary}

An intense rainstorm hit the Middle East between 24 and 27 April 2018, producing heavy flash floods in Israel that claimed the lives of 13 people. A total of 10 of them lost their lives on 26 April in a flash flood that resulted from rain showers with intensities of $>75$-year return period. The study describes the major rain systems affecting Israel on that day and analyses the atmospheric processes leading to their formation. The dominating synoptic feature was a cyclone at all levels that crossed Israel on its way eastward. The rain distribution for the entire storm was not evenly distributed. Three major rain centres were active during 26 April. One, which caused the fatal flood, developed over relatively flat terrain, the second developed upslope of the mountains, i.e. orographic, and the third formed in the Jordan Valley. The synoptic factor supplied the background for the rainstorm, and the mesoscale features determined the locations and times of the major rain events.

The synoptic background of the storm was an upper-level cut-off low that originated in southern Europe and slowed its movement while approaching the Levant. This cut-off low was found to have the highest vorticity with respect to the set of 12 reference storms observed over the study region in the late spring during the last 33 years. The lower levels were dominated by a cyclone centred east of Israel. The implied winds were north-westerly, hence advecting moist air from the Mediterranean inland. During the approach of the upperlevel cyclone, the atmosphere over the study region became conditionally unstable, with instability indices reaching values indicating the potential for thunderstorms. At the same time, the precipitable water increased by a factor of 2 over the study region, which triggered deep moist convection from 25 April onward. The mesoscale distribution of MKI (modified $k$-index) indicated that the instability was considerably higher inland than along the coastal plain. This may explain why most of the rain was observed there. In addition to the lower-level moisture advection, a mid-level band of moist air, extending from Iraq westward, curved cyclonically through Syria and the EM and entered southern Israel from the northwest. The combination of both moisture contributions and instability can explain the severe rain showers over Israel observed during 26 April.

The present study raises several questions for further research. One of them concerns the involvement of closed upper-level cyclones as a major factor for severe rainstorms over the Negev Desert in the late spring. The spring season in the Mediterranean is characterised by a general weakening and reduced frequency of Cyprus lows. Moreover, the late spring is the time at which the descending branch of the Hadley cell takes over the Mediterranean. In light of the above, the specific conditions that lead to the intensification of Rossby waves that lead to their breaking into closed cyclones should be investigated.

The most intense showers associated with the storm studied here were observed when the study region was situated west of the upper-level cyclone where negative vorticity advection is expected. Similar situations were noted by Kahana et al. (2002) in the framework of the Syrian Low, which has produced major floods in the Negev Desert. A similar situation was analysed by Morin et al. (2007), which resulted in a fatal flood in Israel between 31 March and 1 April 2006.

Rain production in convective storms requires the coherent action of many processes acting over broad ranges of space and timescales. In order to provide an adequate description of the factors involved and to get warnings for potential flash floods, such as the one that occurred in Tzafit, there is a need to identify key mechanisms that can only be identified by state-of-the-art regional models, such as the COSMO model used here.

Data availability. ERA5 ECMWF reanalysis data have been downloaded from the Copernicus Climate Data Store (https://cds. climate.copernicus.eu, last access: 25 December 2019) (Copernicus, 2019). Meteosat Second Generation water vapour imageries were retrieved from EUMETSAT data centre (https://navigator. eumetsat.int/product/EO:EUM:DAT:MSG:HRSEVIRI, last access: 1 June 2019) (Kerkmann, 2019). Air back trajectories for detecting moisture transport were retrieved from the site of the NOAA HYSPLIT model (https://www.ready.noaa.gov/HYSPLIT.php, last access: 1 April 2019) (Rolph et al., 2017).

Author contributions. UD conceived the study, set the goals of the article and developed its methodology. IML selected and analysed the data sources. BZ was engaged in the dynamic aspects of the study and their issuing calculations. PK performed the numerical simulation with IMS-COSMO model. All the authors contributed to the interpretation of the results and to writing the manuscript.

Competing interests. The authors declare that they have no conflict of interest. 
Acknowledgements. The authors wish to thank Efrat Morin and Yair Rinat from HUJI for the hydrometric data and the radar images. We are grateful to Noam Halfon and Yoav Levi from the Israel Meteorological Service (IMS) for providing the IMS Cband Doppler radar imagery and the integrated rain maps and to Elyakom Vadislavsky for the MSG IR images and for his assistance and scientific inputs while running the IMS-COSMO model and to Michal Kidron and Guy Keren from HUJI for their help in the preparation of the figures. Baruch Ziv thanks the Israeli Science Foundation (ISF; grant no. 1123/17). We also wish to express our gratitude to the three anonymous referees for their most helpful comments and constructive suggestions which led to substantial improvements of the paper.

Financial support. This research has been supported by the Israel Science Foundation (grant no. 1123/17).

Review statement. This paper was edited by Joaquim G. Pinto and reviewed by three anonymous referees.

\section{References}

Alpert, P. and Ziv, B.: The Sharav cyclone - observations and some theoretical considerations, J. Geophys. Res.-Atmos., 94, 1849518514, https://doi.org/10.1029/JD094iD15p18495, 1989.

Alpert, P., Osetinsky, I., Ziv, B., and Shafir, H.: Semi-objective classification for daily synoptic systems, Application to the Eastern Mediterranean climate change, Int. J. Climatol., 24, 1001-1011, https://doi.org/10.1002/joc.1036, 2004.

Altaratz, O., Levin, Z., and Yair, Y.: Winter thunderstorms in Israel: A study with lightning location systems and weather radar, Mon. Weather Rev., 129, 1259-1266, 2001.

Armon, M., Morin, E., and Enzel, Y.: Overview of modern atmospheric patterns controlling rainfall and floods into the Dead Sea: Implications for the lake's sedimentology and paleohydrology, Quaternary Sci. Rev., 216, 58-73, https://doi.org/10.1016/j.quascirev.2019.06.005, 2019.

Ashbel, D.: Great floods in Sinai Peninsula, Palestine, Syria and the Syrian Desert, and the influence of the Red Sea on their formation, Q. J. Roy. Meteror. Soc., 64, 635-639, 1938.

Bardossy, A. and Filiz, F.: Identification of flood producing atmospheric circulation patterns, J. Hydrol., 313, 4857, https://doi.org/10.1016/j.jhydrol.2005.02.006, 2005.

Becker, J. S., Taylor, H. L., Doody, B. J., Wright, K. C., Gruntfest, E., and Webber, D.: A review of people's behavior in and around floodwater, Weather Clim. Soc., 7, 321-332, https://doi.org/10.1175/WCAS-D-14-00030.1, 2015.

Copernicus: Welcome to the Climate Data Store, available at: https: //cds.climate.copernicus.eu, last access: 25 December 2019.

Copernicus Climate Change Service (C3S): ERA5: Fifth generation of ECMWF atmospheric reanalyses of the global climate, Copernicus Climate Change Service Climate Data Store (CDS), https://cds.climate.copernicus.eu/cdsapp\#!/home (last access: 25 December 2019), 2017.
Corfidi, S. F., Merritt, J. H., and Fritsch, J. M.: Predicting the movement of mesoscale convective complexes, Weather Forecast., 11, 41-46, 1996.

Dayan, U. and Morin, E.: Flash Flood-Producing rainstorms over the Dead Sea, Israel: A Review, in: New Frontiers in Dead Sea paleo-environmental research, edited by: Enzel, Y., Agnon, A., and Stein, M., Geol. S. Am. S., 401, 53-62, https://doi.org/10.1130/2006.2401(04), 2006.

Dayan, U. and Sharon, D.: Meteorological Parameters for Discriminating Between Widespread and Spotty Storms in the Negev, Israel J. Earth Sci., 29, 253-256, 1980.

Dayan, U., Ziv, B., Margalit, A., Morin, E., and Sharon, D.: A severe autumn storm over the middle-east: synoptic and meso-scale convection analysis, Theor. Appl. Climatol., 69, 103-122, 2001.

Diakakis, M., Priskos, G. and Skordoulis, M.: Public perception of flood risk in flash flood prone areas of Eastern Mediterranean: the case of Attica Region in Greece, Int. J. Disast. Risk Re., 28, 404-413, https://doi.org/10.1016/j.ijdrr.2018.03.018, 2018.

Doswell, C.: The Distinction between Large-Scale and Mesoscale Contribution to Severe Convection: A Case Study Example, Weather Forecast., 2, 3-16, https://doi.org/10.1175/15200434(1987)002<0003:TDBLSA>2.0.CO;2, 1987.

Flocas, H. A., Maheras, M. P., Karacostas, T. S., Patrikas, I., and Anagnostopoulos, C.: A 40 year climatological study of relative vorticity distribution over the Mediterranean, Int. J. Climatol., 21, 1759-1778, https://doi.org/10.1002/joc.705, 2001.

Fragoso, M., Tildes Gomes, P.: Classification of daily abundant rainfall patterns and associated large-scale atmospheric circulation types in Southern Portugal, Int. J. Climatol., 28, 537-544, https://doi.org/10.1002/joc.1564, 2008.

Galway, J. G.: The lifted index as a predictor of latent instability, B. Am. Meteorol. Soc., 37, 528-529, 1956.

Geer, I. W.: Glossary of Weather and Climate, American Meteorological Society, Boston, USA, 272 pp., 1996.

Haiden, T., Kann A., Wittmann C., Pistotnik G., Bica B., and Gruber C.: The Integrated Nowcasting through Comprehensive Analysis (INCA) System and Its Validation over the Eastern Alpine Region, Weather Forecast., 26, 166-183, https://doi.org/10.1175/2010WAF2222451.1, 2011.

Harats, N., Ziv, B., Yair, Y., Kotroni, V., and Dayan, U.: Dynamic and thermodynamic predictors for lightning and flash floods in the Mediterranean, Adv. Geophys., 23, 57-64, 2010.

HMSO: Weather in the Mediterranean I: General Meteorology, 2nd ed., Her Majesty's Stationery Office, London, 362, 1962.

Holton, J. R.: An Introduction to Dynamic Meteorology, 2nd Edn., Academic Press, Massachusetts, USA, 507 pp., 1992.

Hoskins, B. J., McIntyre, M. E., and Robertson, A. W.: On the use and significance of isentropic potential vorticity maps, Q. J. Roy. Meteor. Soc., 877-946, https://doi.org/10.1002/qj.49711147002, 1985.

Jacobeit, J., Homann, M., Philipp, A., and Beck, C.: Atmospheric circulation types and extreme areal precipitation in southern central Europe, Adv. Sci. Res., 14, 71-75, 2017.

Kahana, R.: Synoptic Hydro-climatology of Major Floods in the Negev and Arava, Southern Israel, MSc Thesis, Institute of Earth Sciences, The Hebrew University of Jerusalem, Jerusalem, 1999.

Kahana, R., Ziv, B., Enzel, Y., and Dayan, U.: Synoptic climatology of major floods in the Negev Desert, Israel, Int. J. Climatol., 22, 867-882, https://doi.org/10.1002/joc.766, 2002. 
Kalnay, E., Kanamitsu, M., Kistler, R., Collins, W., Deaven, D., Gandin, L., Iredell, M., Saha, S., White, G., Woollen, J., Zhu, Y., Chelliah, M., Ebisuzaki, W., Higgins, W., Janowiak, J., Mo, K. C., Ropelewski, C., Wang, J., Leetmaa, A., Reynolds, R., Jenne, R., and Joseph, D.: The NCEP/NCAR 40 years reanalysis project, B. Am. Meteorol. Soc., 77, 437-472, https://doi.org/10.1175/15200477(1996)077<0437:TNYRP>2.0.CO;2, 1996.

Kerkmann, J.: Applications of Meteosat Second Generation - Meteorological use of the SEVIRI IR3.9 Channel, EUMETSAT, European Organisation for the Exploitation of Meteorological Satellites, available at: http://www.eumetsat.int, last access: 1 June 2019.

Khain, P., Levi, Y., Shtivelman, A., Vadislavsky, E., Brainin, E., and Stav, N.: Improving the precipitation forecast over the Eastern Mediterranean using a smoothed time-lagged ensemble, Meteorol. Appl., 27, e1840, https://doi.org/10.1002/met.1840, 2020.

Khain, P., Levi, Y., Muskatel, H., Shtivelman, A., Vadislavsky, E., and Stav, N.: Effect of shallow convection parametrization on cloud resolving NWP forecasts over the Eastern Mediterranean, Atmos. Res., 247, 105213, https://doi.org/10.1016/j.atmosres.2020.105213, 2021.

Kistler, R., Kalnay, E., Collins, W., Saha, S., White, G., Woollen, J., Chelliah, M., Ebisuzaki, W., Kanamitsu, M., Kousky, V., Van Den Dool, H., Jenne, R., and Fiorino, M.: The NCEP-NCAR 50 year Reanalysis: Monthly means CD-ROM and documentation, B. Am. Meteorol. Soc., 82, 247-267, https://doi.org/10.1175/15200477(2001)082<0247:TNNYRM>2.3.CO;2, 2001.

Kushnir, Y., Dayan U., Ziv B., Morin E., and Enzel Y.: Climate of the Levant: phenomena and mechanisms, in: Quaternary of the Levant: Environments, Climate Change, and Humans, edited by: Enzelm, Y. and Bar-Yosef, O., Cambridge University Press, London, 31-44, 2017.

Kutiel, H.: Spatial Coherence of Monthly Rainfall in Israel, Arch. Meteor. Geophy. B, 31, 353-367, 1982.

Lensky, I. M. and Rosenfeld, D.: Clouds-Aerosols-Precipitation Satellite Analysis Tool (CAPSAT), Atmos. Chem. Phys., 8, 6739-6753, https://doi.org/10.5194/acp-8-6739-2008, 2008.

Liu, W. T.: Statistical relation between monthly mean precipitable water and surface-level humidity over global oceans, Mon. Weather Rev., 114, 1591-1602, https://doi.org/10.1175/15200493(1986)114<1591:SRBMMP>2.0.CO;2, 1986.

Marra, F. and Morin, E.: Use of radar QPE for the derivation of Intensity-Duration-Frequency curves in a range of climatic regimes, J. Hydrol., 531, 427-440, https://doi.org/10.1016/j.jhydrol.2015.08.064, 2015.

Moncrieff, M. W. and Miller, M., J.: The dynamics and simulation of tropical cumulonimbus and squall lines, Q. J. Roy. Meteror. Soc., 102, 373-394, 1976.

Montz, B. E. and Gruntfest, E.: Flash flood mitigation: Recommendations for research and applications, Global Environmental Change Part B: Environmental Hazards, 4, 15-22, https://doi.org/10.1016/S1464-2867(02)00011-6, 2002.

Morin, E., Harats, N., Jacoby, Y., Arbel, S., Getker, M., Arazi, A., Grodek, T., Ziv, B., and Dayan, U.: Studying the extremes: hydrometeorological investigation of a floodcausing rainstorm over Israel, Adv. Geosci., 12, 107-114, https://doi.org/10.5194/adgeo-12-107-2007, 2007.
Porat, A., Halfon, N., and Forshpan, A.: Examining the exceptionality of 25-27 April 2018, in: IMS, 16 August 2018, Israel Meteorological Service, Beit Dagan, Israel, 2018.

Porcù, F., Carrassi, A., Medaglia, C. M., Prodi, F., and Mugnai, A.: A study on cut-off low vertical structure and precipitation in the Mediterranean region, Meteorol. Atmos. Phys., 96, 121-140, 2007.

Rinat, Y., Marra, F., Armon, M., Metzger, A., Levi, Y., Khain, P., Vadislavsky, E., Rosensaft, M., and Morin, E.: Hydrometeorological analysis and forecasting of a $3 \mathrm{~d}$ flash-flood-triggering desert rainstorm, Nat. Hazards Earth Syst. Sci., 21, 917-939, https://doi.org/10.5194/nhess-21-917-2021, 2021.

Rolph, G., Stein, A., and Stunder, B.: Real-time Environmental Applications and Display sYstem: READY, Environ. Model. Softw., 95, 210-228, 2017.

Saaroni, H., Halfon, N., Ziv, B., Alpert, P., and Kutiel, H.: Links between the rainfall regime in Israel and location and intensity of Cyprus lows, Int. J. Climatol., 30, 1014-1025, https://doi.org/10.1002/joc.1912, 2010.

Sharif, H., Jackson, T., Hossain, M., and Zane, D.: Analysis of flood fatalities in Texas, Nat. Hazards Rev., 16, 04014016, https://doi.org/10.1061/(ASCE)NH.1527-6996.0000145, 2015.

Sharon, D.: Rainfall Fields in Israel and Jordan and the Effect of Cloud Seeding on Them, J. Appl. Meteorol., 17, 40-48, 1978.

Sharon, D. and Kutiel, H.: The distribution of rainfall intensity in Israel, its regional and seasonal variations and its climatological evaluation, J. Climatol., 6, 277-291, https://doi.org/10.1002/joc.3370060304, 1986.

Shay-El, Y. and Alpert, P.: A diagnostic study of winter diabatic heating in the Mediterranean in relation to cyclones, Q. J. Roy. Meteor. Soc., 117, 715-747, https://doi.org/10.1002/qj.49711750004, 1991.

Showalter, A., K.: A Stability Index for Thunderstorm Forecasting, B. Am. Meteorol. Soc., 34, 25-252, 1953.

Stein, A. F., Draxler, R. R., Rolph, G. D., Stunder, B. J. B., Cohen, M. D., and Ngan, F.: NOAA's HYSPLIT atmospheric transport and dispersion modeling system, B. Am. Meteorol. Soc., 96, 2059-2077, https://doi.org/10.1175/BAMS-D-14$00110.1,2015$.

Stephan, K., Klink, S., and Schraff, C.: Assimilation of radar derived rain rates into the convective scale model COSMO-DE at DWD, Q. J. Roy. Meteor. Soc., 134, 1315-1326, 2008.

Terti, G., Ruin, I., Anquetin, S., and Gourley, J. J.: A situation-based analysis of flash flood fatalities in the united states, B. Am. Meteorol. Soc., 98, 333-345, https://doi.org/10.1175/BAMS-D-15$00276.1,2017$.

Tsvieli, Y. and Zangvil, A.: Synoptic climatological analysis of Red Sea Trough and non-Red Sea Trough rain situations over Israel, Adv. Geosci., 12, 137-143, https://doi.org/10.5194/adgeo12-137-2007, 2007.

Uccellini, L. W. and Kocin, P. J.: The interaction of jet streak circulations during heavy snow events along the east coast of United States, Weather Forecast., 2, 289-308, 1987.

Uzan, L., Egert, S., Khain, P., Levi, Y., Vadislavsky, E., and Alpert, P.: Ceilometers as planetary boundary layer height detectors and a corrective tool for COSMO and IFS models, Atmos. Chem. Phys., 20, 12177-12192, https://doi.org/10.5194/acp-20-121772020, 2020. 
Yamazaki, A. and Itoh, H.: Vortex-vortex interactions for the maintenance of blocking: Part I: The selective absorption mechanism and a case study, J. Atmos. Sci., 70, 725-742, https://doi.org/10.1175/JAS-D-11-0295.1, 2013.

Zappa, G., Hawcroft, M. K., Shaffrey, L., Black, E., and Brayshaw, O. J.: Extratropical cyclones and the projected decline of winter Mediterranean precipitation in the CMIP5 models, Clim. Dynam., 45, 1727-1738, https://doi.org/10.1007/s00382-014-24268,2015 .
Ziv, B., Dayan, U., Kushnir, Y., Roth, C., and Enzel, Y.: Regional and Global Atmospheric Patterns Governing Rainfall in the Southern Levant, Int. J. Climatol., 26, 55-73, 2006.

Ziv, B., Saaroni, H., Romem, M., Heifetz, E., Harnik, N., and Baharad, A.: Analysis of conveyor belts in winter, Mediterranean cyclones, Theor. Appl. Climatol., 99, 441-455, 2010. 